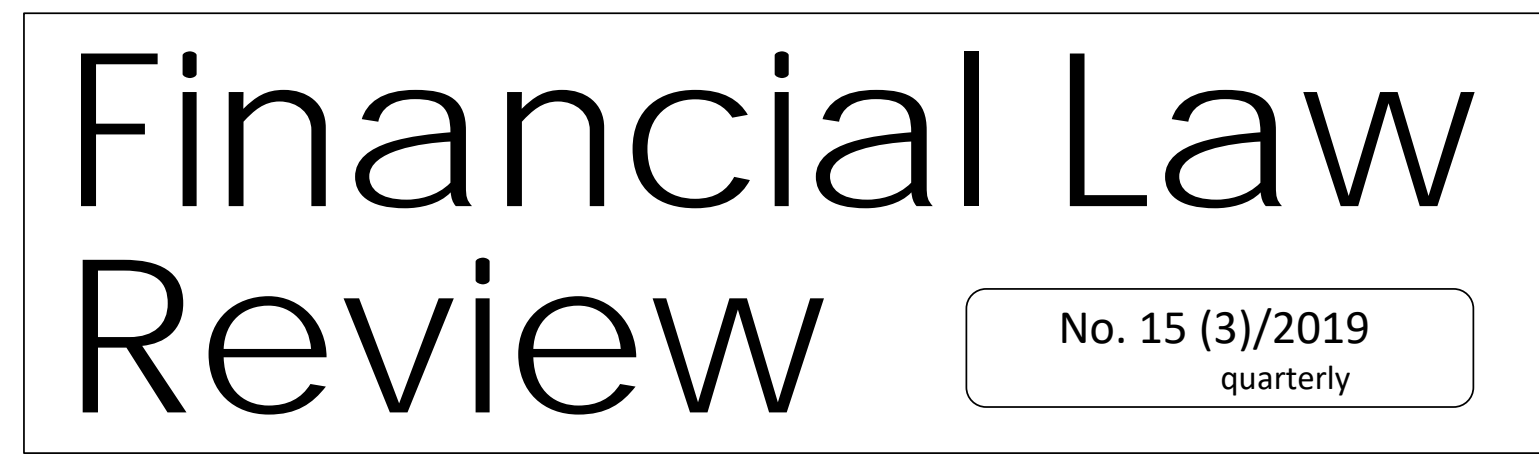

UNIVERSITY OF GDAŃSK • MASARYK UNIVERSITY • PAVEL JOZEF ŠAFÁRIK UNIVERSITY • UNIVERSITY OF VORONEZH http://www.ejoumals.eu/FLR

\title{
IMPACT OF BREXIT ON CORPORATE TAXES IN THE EUROPEAN UNION TEREZAČEJKOV $\AA^{*}$
}

\begin{abstract}
So-called Brexit and its consequences for the United Kingdom and the Member States of the European Union have been a major topic for several years. There are various conjectures, theories and quality research to address the effects of both options - with or without an agreement - on a variety of economic and political areas. In addition to discussions on the conditions for the United Kingdom's withdrawal from the community, the Union has been trying for many years to harmonize the Corporate Tax legislation. There are ambitions to fully unify the rules and to introduce new stricter measures against tax evasion.

In this article, the author examines how one topic affects the other, how important will be the Brexit's role in the Union's efforts to achieve corporate tax harmonization to date, then she analyses some of the theories and expert estimates, compares them with relevant EU legislation focusing on Corporate Tax obligations, and gives an overview of possible endings. In conclusion, the hypothesis that the remaining Member States should unify

\footnotetext{
* PhD Candidate for Financial Law, Department of Financial Law and Economics, Faculty of Law, Masaryk University, Czech Republic. Author specializes in European corporate tax laws and tax evasion. Author of several papers based on research presented at national and international conferences. Contact email: ter.cejkova@gmail.com.
} 
their approach to UK entities concerning tax policies as far as possible in order to avoid confusion and difficulties in taxpayers' legal systems and to open the door to tax evasion, will be refuted or confirmed in the conclusion of the article.

Key words: Corporate Tax, Brexit, tax harmonisation, CC(C)TB.

JEL Classification: K340, K2

\section{Introduction}

The next, and hopefully this time definitive, deadline for the United Kingdom to withdraw from the European Union is set for 31st October this year. Negotiations have been going on for several years and it is still unclear what Brexit will look like and what its consequences will be in all possible fields - economic, political, and in the lives of citizens and non-physical entities.

The Czech Republic is getting ready for the case of the so-called hard Brexit, a variant where the United Kingdom is disconnected without an agreement on the subsequent cooperation of the country with the European Union, by preparing the forthcoming Brexit Act [Ministry of the Interior 2019]. It will primarily regulate issues related to the free movement of citizens, access to the labour market, public health insurance issues, existing supplementary pension insurance and building savings [KPMG 2019]. It is not only from this act of the legislator that the withdrawal of such a strong state from the community, directly or indirectly, will significantly affect a large number of relations.

Each relationship in the legal sense of meaning often entails some tax liability. The abovementioned regulation provides a transitional period for each rule. British citizens will still be subject to EU legislation on taxpayer's tax residency within the Czech Republic for the taxation period in which the Treaty on European Union and the Treaty on the Functioning of the European Union will not be applicable for the first time to the United Kingdom and the conditions of the UK's withdrawal from the EU are not effective yet. However, this will not apply to taxes levied in the form of deductions and for provisions about tax security in these cases the UK citizens will not be considered as residents of the Czech Republic from the moment of Brexit.

A more complicated situation will then arise in the case of taxing of internationally operating corporations, which are expected to be the most affected by Brexit on both sides

[Freedman 2017: 79-90]. Other aspects of a Member State's disconnection, such as free market restrictions, will inevitably lead to economic changes in the EU budgeting sphere, which will have an impact on both direct and indirect tax revenues and in such a case rate changes can be expected. 
The hypothesis of this paper is that the remaining Member States should unify their approach to British entities as much as possible so that the consequent effects do not create confusion and make orientation in taxpayers' legal systems more difficult and do not open the door for tax evasion.

The methods will be used to analyse and interpret relevant legal regulations, compare them and confront them with expert opinions. Due to the rapid development of the topic will be widely drawn from newspapers and reports from political negotiations, for the basic analysis will be used literature.

\section{Corporate Tax Harmonization}

How to motivate taxpayers to pay taxes is a subject to frequent lawmakers' discussions. No entity is happy to pay a significant amount of money gained through its own efforts to the state treasury. But taxes levied on corporations are a significant item of income to the state budget that cannot be replaced, so tax evasion must be avoided as best as possible. Better than strict controls and harsh penalties is to motivate taxpayers positively. There are various ways, simplifying the process is one of them. This includes unifying the rules for different types of taxes, for individual branches, simplifying communication with the tax administrator, and above all is setting fair rates.

While tax rules remain in the hands of the Member States and are considered to be one of the major manifestations of state sovereignty within the European Union, the Community has been in charge of taking measures to prevent tax evasion. This is a problem that extends beyond the borders of a state and even the continent, especially in large international corporations, not only giants such as Google, Amazon, Facebook, Starbucks and others. These companies often avoid paying taxes and optimize income tax, and it is not that difficult for them thanks to their international nature. This phenomenon is growing along with the level of globalization and one of the European Union's main functions is to maintain and improve the conditions of the single market.

The market is changing from local to global at different levels. There is free movement of goods, shifting capital, confrontation of tax systems in the Europe. Although the tax systems of the EU Member States are more or less similar, the rates may vary significantly. Thus, under a single-country taxation regime, companies operating in more than one country open up the possibility of shifting profits to countries with a more favourable tax rate. Popular are intra-corporate loans, the operation of one branch in a state with a higher tax rate as a representative of a branch located in a state with a lower tax rate, which is then the real party to the transaction and profit goes directly to this one. 
A well-known case, the so-called Luxembourg Leaks, is sometimes marked as an important factor in the European Union's efforts to take measures to prevent tax evasion. The financial scandal was unveiled in the autumn of 2014 by the International Consortium of Investigative Journalists (ICIJ, the issue of so-called whistle-blowers). More than 300 major international companies (including PepsiCo, FedEx, IKEA and others) have made an agreement with the state of Luxembourg to help them save hundreds of billions of US Dollars by transferring profits from one state to another across the Luxembourg. Only journalists were punished because such conduct was not illegal at this time.

Unfortunately, this is not an isolated case and such a significant reduction in income to the state budget has a negative impact on a number of tasks of the state in the field of labour and social application of its citizens. There are no means for redistribution to support job creation and employment, the difficulty in eliminating inequalities and promoting social mobility, and foreign investors cannot be encouraged to invest in a given country, with the aim of increasing corporate tax revenues. However, since states cannot fight tax evasion in this way alone, the European Union has taken up this challenge and is working to tackle the problem at transnational level. The European Union seeks to prevent the spill-over of tax obligations between states by introducing a so-called Common Consolidated Corporate Tax Base.

\subsection{Harmonization of Direct Corporate Taxes}

International cooperation is essential to address these issues and tax unification is considered to be a solution due to simplification of rules and better surveillance of the international corporations. It runs on three levels:

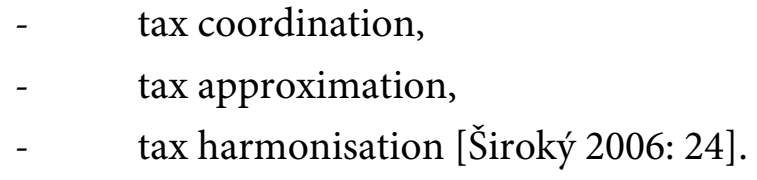

Coordination involves negotiating bilateral or multilateral agreements between states on basic tax institutes - preventing money laundering, reducing harmful tax competition, seeking to set a minimum standard of transparency and systems of exchanging tax-relevant information. A typical result of negotiations on tax coordination is a double tax treaty setting conditions about taxing a subject in only one of the two or more countries being a part to the treaty.

The concept of fiscal approximation appears in the context of the harmonization of relevant legislation in the European Union. This is a phenomenon where the process of regulatory convergence has slowed down or stopped completely. This is most often the case 
for political reasons, or simply because of the reluctance of Member States to continue to act in that direction.

The target level is the tax harmonization, which, to put it simply, represents the resulting state in which the relevant legislation and national tax systems, including the manner of tax administration and process, are aligned at the required level and the applicable rules are the same in different Member States.

Harmonization can be divided into three basic phases:

- first, it is necessary to determine the specific tax to be harmonized,

- then the tax base is harmonized - this is necessary for the fair determination of the tax in the different tax systems and is therefore more fundamental than the following stages,

- $\quad$ harmonization of the tax rate itself [Nerudová 2005: 13-19].

In our case, in addition to indirect taxes such as value added tax, corporate taxation was determined for the above reasons to be harmonised. Negotiations began in 2001 and we are currently in the second phase - harmonizing the method of determination of the tax base. In 2004, a plan to introduce an EU Directive on Common Consolidated Corporate Tax Base (CCCTB) was presented. Such a system already operates in the United States or Canada on the basis of a formula designed to calculate a single tax base distributed among the countries in which the corporation has an operating branch. Individual states are then required to apply tax rates according to their own legislation [COM (2007) 223].

The states characterize their main objectives as the following:

- better use of the benefits of the Single Market,

- achieving fiscal neutrality between domestic and cross-border activities,

- elimination of excessive taxation due to the impossibility of cross-border balancing of profits and losses,

- $\quad$ enabling a better solution to the problem of valuation of cross-border activities between businesses within a multinational company,

- $\quad$ reducing compliance costs.

This proposed regulation was supposed to work alongside the national regulations and to link to them at certain points. But the calculation was very complicated, which, given the fact that it was not mandatory for companies to follow it, did not guarantee its great popularity. Member States have never been able to agree on the text of the Directive therefore it was never effective.

This legislative proposal is followed by the 2016 proposal for a directive. The revision of the recast proposal is primarily divided into two separate provisions - one on the common tax 
base and one on the second phase of consolidation [SWD (2016) 341, SWD (2016) 342], which makes more feasible to switch to the new regime for taxpayers, and for the first time companies will have a single set of rules to calculate their taxable profits within the EU. Further substantial changes are presented in the European Commission press release of 25 October 2016:

- Common Consolidated Tax Base to be mandatory for large multinational groups that have the greatest capacity for aggressive tax planning, ensuring that companies with global revenues above $€ 750$ million annually pay taxes there where they actually make profits,

- $\quad$ to address the current weaknesses in shifting profits for tax purposes,

- to encourage companies to finance their activities through equity or to take advantage of the opportunities of the markets instead of borrowing,

to foster innovation through tax incentives for R\&D activities linked to genuine economic activity.

"The common consolidated corporate tax base does not include corporate tax rates as they fall under the sovereignty of individual Member States. However, a common consolidated corporate tax base will create a more transparent, efficient and fair system for calculating the tax base of cross-border companies, which substantially reforms corporate taxation in the $E U^{\prime \prime}$ [the European Commission 2016].

Transfer pricing options and preferential regimes, which are the basic tools by which internationally operating companies most often commit tax avoidance, will be removed. As the report also states, "as the Common Consolidated Corporate Tax Base will be mandatory for the largest multinationals operating in the EU, companies most at risk of aggressive tax planning will not resort to attempts to circumvent taxation at large." It is obvious that such companies tend to avoid paying taxes in amount that they are entitled to when it's so easy with minimal chance to be prosecuted by the authorities (see the case of the Luxembourg Leaks where no of the companies was sanctioned, because their actions were not actually illegal at the time).

This 'package' comprises three basic elements: (1) the Directive introduces a single set of rules for calculating the corporate tax base, (2) it introduces creation of a single universal sport to file a tax return (so-called one-stop-shop), and 3) explains how a corporation's taxable income is to be distributed among Member States, which is then taxed at the state's own tax rate. In addition to these basic pillars, however, it brings other important innovations: 
- the Common Consolidated Corporate Tax Base Directive (CC(C)TB) is mandatory for all companies generating a worldwide profit of over $€ 750$ million,

- the regulation also unifies the definition of a permanent establishment for the purposes of Tax Law. This is very close to the OECD's definition as well as the of the European Parliament's Recommendation on the Tax Obligation Directive (ATAD) of June 2016,

the directive introduces so-called super-rebate for companies contributing to the economic growth of Member States, and special incentive schemes for innovative start-ups and SMEs, and also encourages the use of non-bank funding sources (equity lending).

The CC(C)TB Directive also includes some elements of the Anti-Tax Avoidance Directive $\mathrm{n}^{\circ}$ II (which, unlike the ATAD $\mathrm{n}^{\circ} \mathrm{I}$, have not yet been approved by the Member States), such as the General Anti-Abuse Rule (GAAR) to address (possibly) all options where abuse of a tax system for the purpose of tax avoidance could occur, provided that such situations do not fall under other specific rules, therefore the provisions will be applied on a subsidiary basis.

The regulation, in its suggested form, also proposes a more efficient double-taxation dispute resolution system within the European Union, which has so far represented some uncertainty and excessive costs for business entities.

Further improvements are brought by the new rules for dealing with inconsistency of the EU rules with third countries' regulations. They are designed to prevent the use of gaps between two different systems to benefit from possible taxation evasion, these gabs are called hybrid mismatches. Hybrid mismatches occur when countries have different rules on the taxation of certain types of income or entities, and corporations can benefit from this situation by completely avoiding taxation in any of these countries. This proposal was made directly at the request of Member States and should resolve the situation [Press release of the European Commission 2016].

\subsection{Harmonization of Indirect Corporate Taxes}

Unlike direct taxes, the harmonization of indirect taxes is simpler, and the progress is much more dynamic. In 1967 the Directive 67/227/EEC introduced the application of value added tax in all Member States instead of the turnover tax levied at that time by some Member States. Given through how many businesses in different countries a product goes before reaching the final customer, this system is way more effective and value added tax currently constitutes an essential component of financing the operations of individual 
Member States and also the European Union as a whole. Rates and tax exemptions were left to rule by the Member States. This provision was followed by the Directive 67/228/EEC defining the subject-matter of taxation and certain important concepts. The EU operates the VIES information system to collect and share information important for the administration of value added tax, and an information system called Inrastat to monitor movement of goods across countries.

Divergent regulations of individual Member States has been removed by the Directive 77/388/EEC, which is currently replaced by Council Directive 2006/112/EC effective since the beginning of 2007. Currently, the specific tax applied (first phase of harmonization) and its basis are successfully harmonized, from which the amount of tax will be calculated (second stage of harmonization). The rate cannot yet be harmonized for several reasons, for example:

- $\quad$ interference with exclusive state sovereignty,

- $\quad$ intervention in the structure of public budgets,

- $\quad$ reducing fiscal policy instruments, and more.

Nevertheless, the rates of tax are adjusted at least in part so that the Directive 91/680/EEC lays down the framework within which the rates may fluctuate, specifying a lower limit of $15 \%$ at the standard rate and at least $5 \%$ at the reduced rate. Some principles will also apply - the country of destination principle (goods are taxed in the country of their consumption), but the European Commission seeks to introduce the country-of-origin principle, but this also implies a uniform rate so that the same goods are not taxed differently according to a country of their origin. It would not therefore be appropriate to argue that value added tax is only approximated within the European Union, because there is the will, but not the right conditions.

Concerning the excise taxes, they are also applied on relevant goods in the country of consumption and harmonization is embodied in the Directive 92/12/EEC and is linked to special directives defining taxable products and their minimum rate [Šmejkal 2018: 167168].

At present, the introduction of the so-called digital tax is also a hot topic. It will affect companies whose activities mostly take place in the digital sphere and which profit comes from online content; some companies even exist only in digital form. Examples include social media companies, collaborative platforms or online content providers. It is particularly easy for such businesses to avoid tax obligations, as the tax administrator has very few tools to thoroughly control them. In addition to the $\mathrm{CC}(\mathrm{C}) \mathrm{TB}$ Directive, the European Commission is also preparing a regulation governing the principles for digital permanent establishments and the principle of profit distribution with adjustments to the Common Consolidated Corporate Tax Base Directive separately or together with a 
recommendation to change the rules vis-à-vis third countries, which is currently preferred by the EU [European Commission 2018].

\subsection{Tax Heavens in the EU}

In terms of the issues discussed, it is worth mentioning the existence of some so-called tax havens in Europe. When you say "tax haven," most people imagine some island states, such as the Seychelles, the Cayman Islands, and others. However, the truth is that there are several such states in the European Union.

Not surprisingly, considered to be tax heavens are some of the above-mentioned countries that have a very low Corporate Income Tax rate, such as Cyprus (10 \%), Ireland (12.5\%), Liechtenstein (7.5-15\%), or Monaco, which exempts businesses from paying income tax in the early years of their operations in the country or, for example, the British Virgin Islands, where a flat-rate tax of $\$ 350$ per year is levied instead of a percentage-based income tax. Virgin Islands do not require companies to keep accounts, submit audit reports, and official records are not accessible to the public.

A somewhat unusual tax haven remains the Netherlands, which has a tax rate of 20-25\%, so not particularly low compared to other Member Stater (the EU average is $23 \%$ ), also strictly monitors the accounting of companies and requires an audit of profit report regularly. However, the business environment in the country is very favourable and offers many advantages to companies, especially to the young and innovative ones, so some companies often move their headquarters there.

The existence of such regimes is highly problematic, as there is nothing to prevent companies from spilling their revenue through some of the above-mentioned countries (methods are for example shifting revenue, creating representative offices, with a truly acting branch located in a more favourable tax country, intra-corporate loans, and others), everything remains legal.

The question is whether the Common Consolidated Corporate Tax Base Directive will help in this case when the real problem lies in the level of the tax rates, which is still left to national adjustments. The Anti-Tax Avoidance Directive (ATAD), which was to be implemented this year, should bring a change. The regulation is based on the principle of a minimum level of protection, which means that each country can impose even stricter rules. The changes will consist mainly in the areas of tax deductibility of interest, taxation of controlled foreign companies (so-called CFC rules), avoidance of so-called hybrid discrepancies, taxation when leaving (exit taxation) and general rules against abuse of law will be established. Expenditure that exceeds $30 \%$ of tax operating profit before interest, 
tax and depreciation (EBITDA) will be considered excessive borrowing costs. Borrowing costs are not only financial expenses such as interest on loans and borrowings, but also related exchange rate differences, interest included in the cost of the asset, interest capitalized on the balance sheet or interest expense from finance leases. The rule will not apply to borrowing costs up to $€ 3$ million, but the Directive allows the limit to be reduced. In any case, the UK will no longer be subject to these regulations, and its own regulation in this area - provision on Diverted Profits Tax introduced in 2015 - may even contravene the EU at some points [Freedman 2017: 79-90].

\section{Involvement of the United Kingdom}

All the efforts of the European Union are carried out with the cooperation of all Member States, including the United Kingdom. Although the negotiations on the country's withdrawal from the community have been going on for several years, it is still unclear when and under what conditions this will happen. However, it is clear that the leaving of such an economically strong state will have an impact on fiscal affairs throughout the European Union.

The UK will lose benefits such as free market movement of goods and capital (the free movement of people is questionable given the fact that the UK has never entered the Schengen area) will have to give up full membership of the EU customs union but also it will cease to be under the jurisdiction of the Court of Justice of the European Union, which may have a significant impact on relations with citizens of other countries where some legal uncertainty may arise.

Considerable losses can occur from those Member States that levy taxes on UK companies located in their territory. Given that the sources of primary and secondary law will cease to apply to these entities, this may be a reason for some companies to move abroad. Of course, if some of them decide to stay, they will need to join the new regime as a third country resident.

\subsection{Customs Duties}

On the part of the European Union as a whole, we will experience a significant decline in the income of the EU budget, which is derived from taxes, duties and membership fees. If there is no bilateral agreement, we will also feel it in monetary and foreign exchange policies. The United Kingdom is an economically very strong player and one of those countries that contributes significantly more to the common EU budget than it receives from it (an estimated $€$ 4-10 billion per year in favour of the European Union over the last 
five years). The absence of these incomes will be a difficult task to handle, but necessary to somehow replace [Šmejkal 2018: 168-169].

In the case of customs, there are two possible solutions - either

a) it will be necessary to create new rules for imports and exports between the United Kingdom and the European Union countries, partly based on mutual agreement, which proves to be a difficult challenge, or

b) the United Kingdom will adopt the existing rules of the European Union and this will establish continuity. Obviously, efforts are being made to minimize the negative impact on both physical and business entities on both sides, and the introduction of new or higher tariffs from one side or the other would certainly represent a considerable burden on their activities and increase the difficulty of making a profit. Such a tendency could lead to the entity's decision to withdraw from one of the markets (given the number of potential customers in general, the UK would probably lose its suppliers) and the negative consequences would be passed on to consumers as well.

Consumers may also be negatively affected by the need to cope with some of the renewed obstacles due to abandoning the free movement of goods in between the parties withholding tax or transfer taxation.

\subsection{Direct Taxes}

In the past, the Member States, including the United Kingdom, have implemented a number of the European Union directives with a direct impact on direct taxation, such as the Mergers Directive, Directive on the Relationship between Subsidiaries and Parent Companies, Directive on Interest and Royalty Taxation, and others. The application of these directives allows, inter alia, to exempt from withholding tax dividends, interest or royalties paid between a subsidiary and a parent company within the EU.

Half of all EU headquarters of third-country multinationals are based in the UK [Allen \& Overy 2016]. "Following Brexit, EU subsidiaries of UK holding companies will not be able to rely on these directives to pay dividends or interest in their UK holding companies free of charge withholding taxes" [Freedman 2017: 79-90]. In order not to lose its competitiveness to other European countries, while avoiding any discriminatory taxation of foreign legal entities operating on its territory, which could cause an outflow of desirable direct investment, it can be assumed that the UK will seek to maintain at least the basic principles of the directives. 
In the past, British finance minister George Osborne then commented on the imminent departure of investors from the UK after its withdrawal from the EU. In 2016, he stated that he would like to avoid this by reducing corporate income tax from $20 \%$ to just $15 \%$, which is the lowest rate of all the world's major economies, according to the Financial Times.

Representatives of the European Union are to anticipate possible negative impacts that have a negative impact on the potential tax benefits of legal entities. The United Kingdom would be close to the above tax havens (e.g. Ireland with a $12.5 \%$ corporate income tax rate), which could be used to attract business entities to move to the United Kingdom and pose a major economic threat to the EU Member States - great loss of tax income, higher price of products that had to be imported from third countries, job losses and more. Judith Freedman, an Oxford professor, is convinced that "it is possible that some companies may move to an EU Member State as a result of the loss of these safeguards, especially cross-border loss relief, although these are currently quite limited in any case" [Freedman 2017: 79-90].

\subsection{Indirect Taxes}

As mentioned above, the harmonization of indirect taxation within the European Union is at a very high level, almost complete (except for the tax rate that remains in the dictation of the Member States). Rise of expenditure on administration and control of indirect tax collection can be expected [OECD 2016], while no significant changes in excise duties are expected to occur.

However, there is a number of possible options for the outcome of changes in the Value Added Tax. There are assumptions that the UK will retain the European Union directives, although it has a possibility to deviate from it, but everything will depend on a concrete agreement between the parties, and neither of them is yet clear on what the ideal situation should look like. The economic interests of both the United Kingdom and the European Union suggest that there will be no significant change in the UK VAT legislation and strong economic relations will be maintained between the two parties.

Apart from the EU rules, the UK has bilateral double taxation treaties with a number of countries. These contracts are usually based on the OECD model, so Brexit should not affect their provisions in any way. However, there may still be a conflict of adjustments in some jurisdictions (e.g. Italy or Germany) where the income of some persons could be taxed far more than at present state [Clements 2016].

\section{Conclusion}


Despite the fact that, as mentioned above, the UK has contributed far more to the EU budget than it has benefited from, its membership of the European Union has helped it to further develop its financial strength and support its position among the world's strongest economies.

The negative effects on finance, and in particular taxes, appear to be predominantly on the UK, while tax regimes in the European Union remain more or less unchanged. Experts talk about the Brexit Tax [OECD 2016], which represents all the financial losses associated with the high costs that the UK will have to incur after its withdrawal to introduce new regimes and restore those whose effectiveness was due to its membership of the European Union paused. The ratio between the level of taxes on income and gross national product per capita will be negatively affected. The United States has also stated in the past that in building economic relations, it intends to focus more on the European Union as a whole [OECD 2016], and a similar approach can be expected of other developed countries with economic interests in Europe.

The hypothesis set out in the introduction of this article, namely that the remaining Member States should unite their attitude to British entities as far as possible so that the consequent effects do not create confusion and difficulties in taxpayers' legal order and open the door to tax evasion is fully confirmed, This is not so much a hypothesis, but rather an intention that the European Union should adopt. It is evident from the above that it is in the best interests of both parties to find a common compromise and to maintain customs and tax cooperation at the highest possible level, and to try to maintain at least partially the single market.

It would also be appropriate for the United Kingdom to remain bound by the existing case law of the Court of Justice of the European Union, as it has built the single European market environment for several decades and plays an important role in all trade relations between Member States of the European Union. Maintaining its effectiveness for the United Kingdom would increase legal certainty for all actors from the two parties and greatly facilitate the introduction of new legislation. Community legislation aimed at avoiding tax evasion by internationally operating corporations is of a very high standard of quality and the United Kingdom could only benefit if it left it effective after leaving the European Union.

As an unfortunate fact remains that, despite the negative effects on the United Kingdom in particular, the European Union will be losing significant revenue to the budget gained by taxing the income of large British corporations operating on its territory, value added tax and, of course, membership fee. Given the economic strength of the leaving member state, this outage will be significant, and it is not yet clear whether and how it would be possible to be replaced. 


\section{References:}

Allen \& Overy: Tax and the Implications of Brexit, Specialist Paper No. 8, 2016.

Clements, P.: Brexit; Tax Implications for Multinationals, Tax Journal, 2016.

Freedman, J.: Tax and Brexit, Oxford Review of Economic Policy, n. S1, 2017.

Nerudová, D.: Harmonizace daových systém zemí Evropské unie [Harmonization of tax systems of European Union], Praha: Aspi, a.s., 2005.

OECD: The Economic Consequences of Brexit: A Taxing Decision, OECD Economic Policy Paper No. 16, Paris, Organization for Economic Cooperation and Development, 2016.

Široký, J. Daně v Evropské unii [Taxes in the European Union], Praha, Linde Praha, 2010.

ŠMEJKAL, V. (ed.).: Evropská unie po brexitu. Právně-institucionální budoucnost evropské integrace [The European Union after Brexit. The legal-institutional future of European integration], Praha: Wolters Kluwer CR, 2018.

\section{Internet Resources:}

Altaxo: Daňové ráje $\mathrm{v}$ Evropě [Tax Heavens in Europe], 2015. Available at: https://www.altaxo.cz/poradna/zahranicni-spolecnosti/danove-raje-v-evrope.

Communication from the Commission to the European Parliament, the Council and the European Economic and Social Committee: Implementing the Community Program for Growth and Jobs and Improving the Competitiveness of Businesses in the EU:

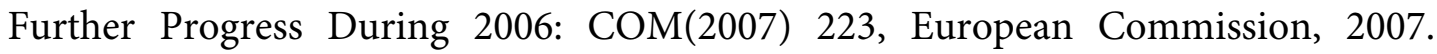
Available at: http://eurlex.europa.eu/LexUriServ/LexUriServ.do?uri=COM:2007:0223:FIN:CS:PDF.

ČTK: Británie by mohla být daňovým rájem. Po brexitu chce firmám snížit daně [Britain could be a tax haven. After Brexit, companies want to reduce taxes], iDnes.cz, 2016. Available at: https://www.idnes.cz/ekonomika/zahranicni/britsky-ministr-financichce-po-brexitu-snizit-firmam-dane.A160704_141126_eko_euro_kris

European Commission: Fair Taxation of the Digital Economy, 2018. Available at: https://ec.europa.eu/taxation_customs/business/company-tax/fair-taxation-digitaleconomy_en

European Commission: The Commission proposes a fundamental reform of the corporate tax for the EU, 2016. Available at: https://europa.eu/rapid/press-release_IP-163471_cs.htm

European Parliament: Daňové úniky: Podle poslanců podrývají členské státy důverryhodnost EU [Tax evasion: According to MEPs, Member States undermine the EU's credibility], 2018. Available at:

http://www.europarl.europa.eu/news/cs/headlines/economy/20180126STO94140/da nove-uniky-podle-poslancu-podryvaji-clenske-staty-duveryhodnost-eu

Evropský semester: Zdanění [European semester: Taxation], 2017. Available at: https://ec.europa.eu/info/sites/info/files/file_import/european-semester_thematicfactsheet_taxation_cs_0.pdf

ICIJ: 'Lux Leaks' Revelations Bring Swift Response Around World, 2014. Available at: https://www.icij.org/investigations/luxembourg-leaks/lux-leaks-revelations-bringswift-response-around-world/ 
ICIJ: Explore the Documents: Luxembourg Leaks Database, 2014. Available at: https://www.icij.org/investigations/luxembourg-leaks/explore-documentsluxembourg-leaks-database/

Anoušek, R.: Projekt opatření proti daňovým únikům při správě DPH [Project of measures against VAT evasion], Diploma Thesis, University of Tomáš Bata in Zlín, 2009. Available at:

https://digilib.k.utb.cz/bitstream/handle/10563/9631/janou\%C5\%A1ek_2009_dp.pdf ?sequence $=1$ \&isAllowed $=\mathrm{y}$

OECD: The Economic Consequences of Brexit: A Taxing Decision, 2016. Available at: https://www.oecd.org/unitedkingdom/the-economic-consequences-of-brexit-ataxing-decision.htm

Pěknicová, K.: Ministerstvo vnitra připravilo brexitový zákon pro případ tvrdého brexitu [The Ministry of the Interior has prepared a Brexit law for the case of hard Brexit], Ministry of Interior, 2019. Available at: https:/www.mvcr.cz/clanek/ministerstvovnitra-pripravilo-brexitovy-zakon-pro-pripad-tvrdeho-brexitu.aspx

Prášilová, P.: Stručně a jasně: Společný (konsolidovaný) základ daně z př́ijmu právnických osob [Briefly and clearly: Common (consolidated) corporate tax base], Danovereformy.cz, 2016. Available at: https://www.danovereformy.eu/korporatnidane/articles/strucne-a-jasne-spolecny-konsolidovany-zaklad-dane-z-prijmupravnickych-osob

Proposal for a Council Directive on a Common Corporate Tax Base, COM(2016) 685, 2016. Available at:

https://ec.europa.eu/taxation_customs/sites/taxation/files/com_2016_685_en.pdf

Svoboda, F.; Cigánková, K.: Brexit změní uplatňování srážkových daní a zajištění daně [Brexit will change the application of withholding taxes and tax security], KPMG online, 2019. Available at: https://danovky.cz/cs/brexit-zmeni-uplatnovanisrazkovych-dani-a-zajisteni-dane

Taxation and Customs Union. Available at:

https://ec.europa.eu/taxation_customs/business/company-tax_en. 